\title{
Fabrication of Z-scheme $\mathrm{BiVO}_{4} / \mathrm{GO} / \mathrm{g}-\mathrm{C}_{3} \mathrm{~N}_{4}$ Photocatalyst with Efficient Visble-light Photocatalytic Performance
}

\author{
XU Shichao ${ }^{1}$, ZHU Tianzhe ${ }^{1}$, QIAO Yang ${ }^{2}$, BAI Xuejian ${ }^{2}$, TANG Nan ${ }^{1}$, ZHENG Chunming ${ }^{2}$ \\ (1. School of Environmental Science and Engineering, Tiangong University, Tianjin 300389, China; 2. School of Chemistry and \\ Chemical Engineering, Tiangong University, Tianjin 300389, China)
}

\begin{abstract}
Fabricating Z-scheme photocatalysts is a promising method for improving photocatalytic activity by effectively enhancing charge separation. A new Z-scheme $\mathrm{BiVO}_{4} / \mathrm{GO} / \mathrm{g}-\mathrm{C}_{3} \mathrm{~N}_{4}$ photocatalyst was prepared by two steps of impregnation-calcination and hydrothermal method, and then characterized by different methods. In the photocatalytic process of $\mathrm{BiVO}_{4} / \mathrm{GO} / \mathrm{g}-\mathrm{C}_{3} \mathrm{~N}_{4}$, GO nanosheet act as fast transmission channels between $\mathrm{BiVO}_{4}$ and g- $\mathrm{C}_{3} \mathrm{~N}_{4}$ and can suppress electron-hole recombination, which significantly promotes the charge separation and improves the redox ability of the ternary heterojunction. The ternary photocatalyst has good photocatalytic degradation of Rhodamine $\mathrm{B}(\mathrm{RhB})$ as compared to the single-component or binary composite. It is capable of degrading $85 \%$ of $\mathrm{RhB}$ in 120 min under visible light irradiation and the hole $\left(\mathrm{h}^{+}\right)$plays a major role in the reaction. This work provides a simple preparation method for a ternary photocatalyst system in which $\mathrm{g}-\mathrm{C}_{3} \mathrm{~N}_{4}$ coupled with $\mathrm{BiVO}_{4}$ by GO to significantly improve photocatalytic activity.
\end{abstract}

Key words: $\mathrm{BiVO}_{4} ; \mathrm{g}-\mathrm{C}_{3} \mathrm{~N}_{4} ; \mathrm{GO}$; ternary photocatalyst; Z-scheme heterojunction

In recent decades, organic dyes have been widely used in many industrial production process, such as clothing, food processing, medicine, spray and rubber manufacturing industries ${ }^{[1-2]}$. The emissions of organic dye wastewater from these industries are growing and become a challenge to human. Photocatalytic decomposition of organic dyes in aquatic environment on semiconductor catalysts, such as $\mathrm{TiO}_{2}{ }^{[3]}, \mathrm{WO}_{3}{ }^{[4]}, \mathrm{ZnO}^{[5]}, \mathrm{MoS}_{2}{ }^{[6-7]}$, is a potential technique to tackle the organic pollution. However, the wide band gap and poor quantum yield of these traditional semiconductor catalysts significantly limit their efficient absorption of visible-light, which is essential for photocatalysts, and result in low photocatalytic efficiency.

Graphitic carbon nitride $\left(\mathrm{g}-\mathrm{C}_{3} \mathrm{~N}_{4}\right)$, a non-metal polymeric visible-light driven photocatalyst with suitable band gap (around $2.7 \mathrm{eV}$ ) and valence band (around $1.5 \mathrm{eV}$ ) has received intense interest in photocatalysis community owing to its excellent chemical stability, relatively low cost and non-toxicity ${ }^{[8-9]}$. Nevertheless, pure g- $\mathrm{C}_{3} \mathrm{~N}_{4}$ faces high recombination rate of photogenerated carriers, inadequate visible-light absorption range and small specific surface area ${ }^{[10]}$. Tremendous attempts have been made to make up for these shortcomings, and a Z-scheme photocatalytic system would be a better approach to tackle the problems. An electron mediator or redox shuttle was applied in Z-scheme to regulate charge transfer, creating spatial isolation of photogenerated carriers, more positive valence band potential and more negative conduction band ${ }^{[11]}$. The system can inhibit the recombination of electrons-holes pairs, and subsequently improve visiblelight induced photocatalytic performance. Recently, many $\mathrm{Z}$-scheme photocatalysts have been prepared to degrade hazardous organic compounds, such as $\mathrm{g}_{-} \mathrm{C}_{3} \mathrm{~N}_{4} / \mathrm{TiO}_{2}{ }^{[12]}$, $\mathrm{MoO}_{3} / \mathrm{g}-\mathrm{C}_{3} \mathrm{~N}_{4}{ }^{[13]}, \mathrm{g}-\mathrm{C}_{3} \mathrm{~N}_{4} / \mathrm{ZnO}^{[14]}, \mathrm{SnO}_{2} / \mathrm{Zn}_{2} \mathrm{SnO}_{4}{ }^{[15]}$.

Bismuth vanadate $\left(\mathrm{BiVO}_{4}\right)$ possesses relatively narrow bandgap $(\sim 2.43 \mathrm{eV})$ and valence band $(\sim 2.75 \mathrm{eV})$, high chemical stability and remarkable energy conversion, and can act as a photocatalyst to degrade organic pollutants ${ }^{[16-17]}$. However, for pure $\mathrm{BiVO}_{4}$, there are problems such as large particle size, small specific surface area, low visible light absorption, and high electron-hole recombination rate, which subsequently leads to low photocatalytic activity ${ }^{[18]}$. Therefore, it is necessary to select suitable semiconductor and recombine $\mathrm{BiVO}_{4}$ into a $\mathrm{Z}$ scheme heterojunction, which could promote the separa-

Received date: 2019-07-23; Revised date: 2019-11-05

Foundation item: National Natural Science Foundation of China (51772208, 51678409); Natural Science Foundation of Tianjin (17JCYBJC15900)

Biography: XU Shichao (1975-), male, PhD, associate professor. E-mail: xushichao@tjpu.edu.cn 许世超(1975-), 男, 博士, 副教授. E-mail: xushichao@tjpu.edu.cn 
tion of photogenerated carriers to improve the photocatalytic efficiency. Moreover, GO (graphene oxide) owns outstanding electrical conductivity, excellent mechanical properties and high surface area, and could be applied in Z-scheme system as a cocatalyst to improve electron transfer rates and photocatalytic activity ${ }^{[11,19]}$.

In this work, a new photocatalyst with a ternary heterojunction, $\mathrm{BiVO}_{4} / \mathrm{GO} / \mathrm{g}-\mathrm{C}_{3} \mathrm{~N}_{4}$, was prepared by a twostep method. The binary composite $\mathrm{GO} / \mathrm{g}-\mathrm{C}_{3} \mathrm{~N}_{4}$ was synthesized by impregnation-calcination method and combined with $\mathrm{BiVO}_{4}$ to form a ternary heterojunction. The photocatalytic performance of the ternary system $\left(\mathrm{BiVO}_{4} /\right.$ $\left.\mathrm{GO} / \mathrm{g}-\mathrm{C}_{3} \mathrm{~N}_{4}\right)$, the binary system $\left(\mathrm{GO} / \mathrm{g}-\mathrm{C}_{3} \mathrm{~N}_{4}\right)$ and single systems $\left(\mathrm{g}-\mathrm{C}_{3} \mathrm{~N}_{4}\right.$ and $\left.\mathrm{BiVO}_{4}\right)$ under visible-light radiation, was systematically evaluated by Rhdamine B degradation, and the mechanism of photocatalytic reaction of the $\mathrm{Z}$-scheme heterojunction $\mathrm{BiVO}_{4} / \mathrm{GO} / \mathrm{g}-\mathrm{C}_{3} \mathrm{~N}_{4}$ was discussed in detail.

\section{Experimental}

\subsection{Materials and synthesis}

Dicyandiamide, bismuth nitrate pentahydrate $\left(\mathrm{Bi}\left(\mathrm{NO}_{3}\right)_{3}\right.$. $\left.5 \mathrm{H}_{2} \mathrm{O}\right)$, ammonium metavanadate $\left(\mathrm{NH}_{4} \mathrm{VO}_{3}\right)$, were purchased from Aladdin Chemical Reagent Co. Ltd (Shanghai, China). Graphene oxide (GO) powder was purchased from Suzhou Hengqiu Graphene Co., Ltd., China.

\subsubsection{Preparation of the $\mathrm{GO} / \mathrm{g}-\mathrm{C}_{3} \mathrm{~N}_{4}$}

$\mathrm{GO} / \mathrm{g}-\mathrm{C}_{3} \mathrm{~N}_{4}$ binary photocatalytic heterojunction was prepared by an impregnation-calcination method according to previous report with some modifications ${ }^{[20]}$. The $\mathrm{GO} / \mathrm{g}-\mathrm{C}_{3} \mathrm{~N}_{4}$ samples were synthesized as follows: $36 \mathrm{mg}$ $\mathrm{GO}$ was put into $300 \mathrm{~mL}$ water, stirred and ultrasound for $0.5 \mathrm{~h}$. Then $120 \mathrm{mg}$ dicyandiamide was dispersed in mixture solution. The mixture solution was ceaselessly stirred at $80{ }^{\circ} \mathrm{C}$ for $4 \mathrm{~h}$, and then dried in an oven at $80{ }^{\circ} \mathrm{C}$ for $8 \mathrm{~h}$. In this process, dicyandiamide could deposit on the GO surface via electrostatic interactions. The as-prepared gray solid samples was put into crucibles with the covers, and then heated to $520{ }^{\circ} \mathrm{C}$ for $2.5 \mathrm{~h}$ at a heating rate of $5{ }^{\circ} \mathrm{C} \cdot \mathrm{min}^{-1}$ and kept at $520{ }^{\circ} \mathrm{C}$ for $2 \mathrm{~h}$ in a quartz tube under flowing pure argon. The calcined product was ground to powder, washed with deionized water for three times and then dried at $60{ }^{\circ} \mathrm{C}$. The ultimate pale-yellowish green $\mathrm{GO} / \mathrm{g}-\mathrm{C}_{3} \mathrm{~N}_{4}$ powder was prepared.

\subsubsection{Preparation of the $\mathrm{BiVO}_{4} / \mathrm{GO} / \mathrm{g}-\mathrm{C}_{3} \mathrm{~N}_{4}$ ternary photocatalyst}

Firstly, $0.7 \mathrm{mmol} \mathrm{Bi}\left(\mathrm{NO}_{3}\right)_{3} \cdot 5 \mathrm{H}_{2} \mathrm{O}$ and $0.7 \mathrm{mmol} \mathrm{NH}_{4} \mathrm{VO}_{4}$ were completely dissolved in $10 \mathrm{~mL} 2 \mathrm{~mol} / \mathrm{L} \mathrm{HNO}_{3}$ aqueous solution and $10 \mathrm{~mL}$ deionized water, respectively.
Secondly, different amounts of $\mathrm{GO} / \mathrm{g}-\mathrm{C}_{3} \mathrm{~N}_{4}$ were added to $\mathrm{Bi}\left(\mathrm{NO}_{3}\right)_{3}$ mixture solution and dispersed by $0.5 \mathrm{~h}$ stirring and ultrasound, then $\mathrm{NH}_{4} \mathrm{VO}_{4}$ aqueous solution was put into the above mixture solution. In order to get the precursor, the resulting pale yellow suspension was vigorous stirred for $1 \mathrm{~h}$ at room temperature. Then it was poured into a $50 \mathrm{~mL}$ Teflon-lined autoclave, heated at $180{ }^{\circ} \mathrm{C}$ for $7 \mathrm{~h}$, and naturally cooled to room temperature. The obtained precipitate was washed with deionized water and absolute ethanol for 3 times, respectively. Finally, the samples were dried at $60{ }^{\circ} \mathrm{C}$ for $4 \mathrm{~h}$. The composite photocatalysts having different mass ratios of $\mathrm{BiVO}_{4}$ to $\mathrm{GO} / \mathrm{g}-\mathrm{C}_{3} \mathrm{~N}_{4}$ were recorded as $8: 2,6: 4,4: 6$ and $2: 8$ (the former is $\mathrm{BiVO}_{4}$ occupancy). Here the photocatalytic heterojunctions were denoted as B8GC2, B6GC4, B4GC6, B2GC8, respectively according to these different mass ratios. Meanwhile, for comparison, pure $\mathrm{BiVO}_{4}$ was also prepared in the same manner without the addition of $\mathrm{GO} / \mathrm{g}-\mathrm{C}_{3} \mathrm{~N}_{4}$.

\subsection{Characterizations}

X-ray diffraction (XRD) patterns were characterized on a D/Max-2500 X-ray diffractometer (Rigaku, Japan) with $\mathrm{Cu}-\mathrm{K} \alpha$ radiation at a scan rate $(2 \theta)$ of $0.05\left(^{\circ}\right) / \mathrm{s}$ in the range of $3^{\circ}-70^{\circ}$. The microstructures were examined by a transmission electron microscope (TEM) (Hitachi H7650, HITACHI, Japan) and high-resolution transmission electron micrographs (HRTEM) (TecnaiG2 F20, FEI, America). The sizes and morphologies were collected with a field emission scanning electron microscope (Gemini SEM500, ZEISS, Germany). UV-visible absorbance spectra of the dry-pressed disk samples were obtained by means of a UV-visible spectrophotometer (UV-2600, Shimadzu, Japan) in the range of 200-800 nm with $\mathrm{BaSO}_{4}$ as a reflectance standard. The chemical bonding status of the samples were analyzed on an FT-IR spectro-meter (FTIR-650, Gangdong Technology, China). The specific surface area of the samples were measured through a mesoporous surface physical adsorber (NOVA4200e, Quantachrome, America). Photoluminescence (PL) spectra were measured under $315 \mathrm{~nm}$ excitation wavelength by a Fluorescence Spectrophotometer (F380, Gangdong Technology, China).

\subsection{Photoelectrochemical measurements}

All photoelectrochemical studies were carried out by an electrochemical workstation (CHI760E, Chenhua, China) in a standard three-electrode system which used the asprepared samples as the working electrodes, the platinum wire as the counter electrode, and $\mathrm{Ag} / \mathrm{AgCl}$ electrode as the reference electrode. $0.1 \mathrm{~mol} / \mathrm{L} \mathrm{Na}_{2} \mathrm{SO}_{4}$ aqueous solution was used as the electrolyte. The working electrodes were prepared as follows: $0.2 \mathrm{~g}$ photocatalyst was ground 
and $0.5 \mathrm{~mL}$ anhydrous ethanol with the ultrasonic dispersion to make uniform suspension slurry. Then, the obtained slurry was smeared onto a $2 \mathrm{~cm} \times 2 \mathrm{~cm}$ F-doped $\mathrm{SnO}_{2}$ - coated conducting glass (FTO glass) using spincoating strategy for twice. Photocurrent curves were measured using an Amperometric I- $t$ curves method under a $30 \mathrm{~s}$ intermittent irradiation, and the initial voltage was $1.2 \mathrm{~V}$. Electrochemical impedance spectra (EIS) were obtained in the frequency range of $0.01-100,000$ $\mathrm{Hz}$ at initial voltage of $0 \mathrm{~V}$.

\subsection{Evaluation of photocatalytic activity}

A $500 \mathrm{~W}$ Xe lamp (Beijing AuLight, China) was utilized as a visible-light source with $400 \mathrm{~nm}$ cut-off filters. The degradation of $\mathrm{RhB}$ was used as the evaluation standard for the photocatalytic ability of the sample. The photocatalytic degradation products of $\mathrm{RhB}$ were analyzed using an UV-Vis spectrophotometer (UV-2600, SHIMADZU, Japan) at $553 \mathrm{~nm}$.

In the photocatalytic performance evaluation experiment, $10 \mathrm{mg}$ catalysts was added into the $\mathrm{RhB}(20 \mathrm{~mL}$, $20 \mathrm{mg} \cdot \mathrm{L}^{-1}$ ) each time. In order to reach adsorption- desorption equilibrium, the solution was stirred for $30 \mathrm{~min}$ in the dark before the irradiation. Suspensions with dosage of $4.0 \mathrm{~mL}$ were withdrawn and analyzed regularly. After suspensions were centrifuged (8000 r/min, $10 \mathrm{~min}$ ) for photocatalyst removal, detected at $553 \mathrm{~nm}$ absorbance by UV-Vis spectrophotometer.

The photocatalytic degradation efficiency $(E)$ was obtained for measurement and calculation according to Eq. (1):

$$
E=\left(1-\frac{C}{C_{0}}\right) \times 100 \%=\left(1-\frac{A}{A_{0}}\right) \times 100 \%
$$

Where $C$ is the concentration of $\mathrm{RhB}$ at different time, $C_{0}$ is the initial concentration at the $\mathrm{RhB}$ adsorption equilibrium, $A$ and $A_{0}$ are the corresponding absorption values.

\section{Results and discussion}

\subsection{Optical, structural and morphological characteristics}

The reflective patterns of as-prepared composite samples were studied by powder XRD to infer the phase structures. As shown in Fig. 1(a), the strongest diffraction (002) peak near $2 \theta=27.4^{\circ}$ corresponds to an interplanar distance of the conjugated aromatic system of $0.326 \mathrm{~nm}$, which reflects the interlayer tight accumulation of aromatic rings. Another apparent additional (001) peak relates to an in-plane structural packing motif which interlayer space is $0.672 \mathrm{~nm}^{[21]}$. In addition, due to incomplete pyrolysis of reactant, the weak diffraction peaks of intermediates were observed in the XRD patterns.
In addition, compared to the crystalline structures of pure $\mathrm{BiVO}_{4}$, no matter whether it is the shape or position, the added compound has little effect on the characteristic peak of pure $\mathrm{BiVO}_{4}$. Therefore, $\mathrm{BiVO}_{4}$ in heterojunction maintains a stable crystal structure, which isn't affected by the introduction of $\mathrm{GO} / \mathrm{g}-\mathrm{C}_{3} \mathrm{~N}_{4}$. Due to no introduction of other new peaks, the combination of $\mathrm{BiVO}_{4}$ and $\mathrm{GO} / \mathrm{g}-\mathrm{C}_{3} \mathrm{~N}_{4}$ don't generate impurities, revealing that GO, g- $\mathrm{C}_{3} \mathrm{~N}_{4}$ and $\mathrm{BiVO}_{4}$ coexist in the ternary nanocomposite photocatalysts.

FT-IR spectra (Fig. 1(b)) show that graphite oxide exhibits strong hydroxyl stretching vibration absorption peak near $3477 \mathrm{~cm}^{-1}$. The $\mathrm{C}=\mathrm{O}$ stretching vibration peak on the carboxyl group of graphene oxide appears at $1790 \mathrm{~cm}^{-1}$. The absorption peak at $1685 \mathrm{~cm}^{-1}$ may be the absorption peak due to the bending vibration of $\mathrm{C}-\mathrm{OH}^{[22]}$. The peak at $1116 \mathrm{~cm}^{-1}$ derives from the vibration of graphene oxide $\mathrm{C}-\mathrm{O}-\mathrm{C}$. Therefore under the experimental conditions, at least 4 functional groups of $-\mathrm{OH},-\mathrm{COOH}, \mathrm{C}-\mathrm{O}-\mathrm{C}$ and $-\mathrm{C}=\mathrm{O}$ exist in the graphite oxide ${ }^{[23]}$. The infrared spectrum of $\mathrm{GO} / \mathrm{g}-\mathrm{C}_{3} \mathrm{~N}_{4}$ shows that the region of 1200 $1650 \mathrm{~cm}^{-1}$ contains several strong peaks with peaks at $1232,1326,1415,1567$ and $1642 \mathrm{~cm}^{-1}$, which are typical $\mathrm{CN}$ heterocycles. The characteristic peak caused by tensile vibration and the peak at $806 \mathrm{~cm}^{-1}$ is the characteristic breathing pattern of the triazine unit.
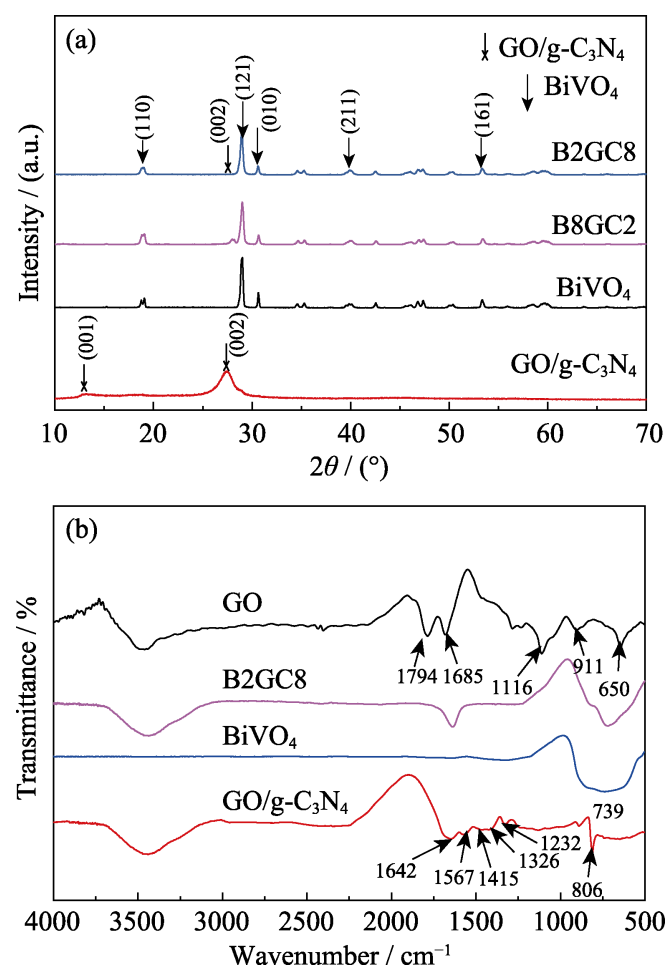

Fig. 1 XRD patterns of $\mathrm{BiVO}_{4}, \mathrm{~g}_{-} \mathrm{C}_{3} \mathrm{~N}_{4} / \mathrm{GO}, \mathrm{B} 2 \mathrm{GC} 8$, and $\mathrm{BiVO}_{4} /$ $\mathrm{GO} / \mathrm{g}-\mathrm{C}_{3} \mathrm{~N}_{4}$ (a), and FT-IR spectra of the as-prepared $\mathrm{GO}, \mathrm{GO} /$ g- $\mathrm{C}_{3} \mathrm{~N}_{4}, \mathrm{BiVO}_{4}, \mathrm{BiVO}_{4} / \mathrm{GO} / \mathrm{g}-\mathrm{C}_{3} \mathrm{~N}_{4}$ (b) 
No other peaks were observed in $\mathrm{BiVO}_{4} / \mathrm{GO} / \mathrm{g}-\mathrm{C}_{3} \mathrm{~N}_{4}$ spectrum, probably due to the reduction of graphene oxide during the calcination. Vibration band at $739 \mathrm{~cm}^{-1}$ is generated by $v\left(\mathrm{VO}_{4}{ }^{3-}\right)$ stretching vibration ${ }^{[24]}$. The part of primary bands of $\mathrm{g}-\mathrm{C}_{3} \mathrm{~N}_{4}$ and $\mathrm{BiVO}_{4}$ are included in the ternary nanocomposite, indicating that the $\mathrm{BiVO}_{4} /$ $\mathrm{GO} / \mathrm{g}-\mathrm{C}_{3} \mathrm{~N}_{4}$ ternary photocatalyst was synthesized successfully.

To examine chemical composition and states of samples, the prepared photocatalysts were analyzed by XPS characterization (Fig. 2). It is obvious that the detection spectrum of the $\mathrm{BiVO}_{4} / \mathrm{GO} / \mathrm{g}-\mathrm{C}_{3} \mathrm{~N}_{4}$ can determine that the sample contains only $\mathrm{Bi}, \mathrm{V}$ and $\mathrm{O}$ elements for $\mathrm{BiVO}_{4}$, and $\mathrm{C}, \mathrm{N}$ and $\mathrm{O}$ elements for $\mathrm{GO} / \mathrm{g}-\mathrm{C}_{3} \mathrm{~N}_{4}$, and no impurities (Fig. 2(a)). According to the Gaussian curvefitted signal deconvolution, the high-resolution $\mathrm{N} 1 \mathrm{~s}$ spectrum of $\mathrm{BiVO}_{4} / \mathrm{GO} / \mathrm{g}-\mathrm{C}_{3} \mathrm{~N}_{4}$ has $\mathrm{N}$ species in different chemical environments (Fig. 2(b)). The highest N1s peak at $398.6 \mathrm{eV}$ corresponds to $\mathrm{sp}$ 2-hybridized nitrogen $(\mathrm{C}=\mathrm{N}-\mathrm{C})$. Two other weak N1s peaks locating at 399.8 and $401.5 \mathrm{eV}$ can be assigned to tertiary nitrogen $\left(\mathrm{N}-(\mathrm{C})_{3}\right)$ and amino functional groups $(\mathrm{C}-\mathrm{N}-\mathrm{H})$, respectively. The weak $\mathrm{C} 1 \mathrm{~s}$ peak $(284.6 \mathrm{eV})$ in the $\mathrm{BiVO}_{4}$ sample spectrum was produced by the XPS instrument itself contaminating hydrocarbons, whereas the peak of the $\mathrm{GO} / \mathrm{g}-\mathrm{C}_{3} \mathrm{~N}_{4}$ sample at $288.08 \mathrm{eV}$ was attributed to the sp2-hybridized carbon in $\mathrm{N}$-containing aromatic $\operatorname{ring}(\mathrm{N}-\mathrm{C}=\mathrm{N})$, which positively shifted to $288.38 \mathrm{eV}$ for the $\mathrm{BiVO}_{4} / \mathrm{GO} / \mathrm{g}-\mathrm{C}_{3} \mathrm{~N}_{4}$ sample in Fig. 2(c) ${ }^{[25]}$. The Bi4f spectrum (Fig. 2(d)) of pristine $\mathrm{BiVO}_{4}$ at 159.08 and $164.48 \mathrm{eV}$ are respectively corresponding to $\mathrm{Bi} 4 \mathrm{f} 7 / 2$ and $\mathrm{Bi} 4 \mathrm{f} 5 / 2$ of $\mathrm{Bi}^{3+}$ induced, while these two peaks in the spectrum of $\mathrm{BiVO}_{4} / \mathrm{GO} / \mathrm{g}$ $\mathrm{C}_{3} \mathrm{~N}_{4}$ shifted to 158.98 and $164.38 \mathrm{eV}$, respectively. Compared to $\mathrm{Bi} 4 \mathrm{f}$ of pure $\mathrm{BiVO}_{4}, \mathrm{~B} 2 \mathrm{GC} 8$ exhibits a weak blue shift effect, demonstrating that $\mathrm{GO} / \mathrm{g}-\mathrm{C}_{3} \mathrm{~N}_{4}$ acts as an electron acceptor and promotes the carrier separation.

TEM images (Fig. 3(a, b) show that the layered $g-\mathrm{C}_{3} \mathrm{~N}_{4}$ tightly anchors on the wrinkled surface of the GO to form a stable heterojunction in the $\mathrm{GO} / \mathrm{g}-\mathrm{C}_{3} \mathrm{~N}_{4}$ composite. After hydrothermal reaction, $1-5 \mu \mathrm{m} \mathrm{BiVO}_{4}$ crystal particles uniformly distributed on the surface of $\mathrm{GO} / \mathrm{g}-\mathrm{C}_{3} \mathrm{~N}_{4}$, and a ternary photocatalyst was synthesized. In Fig. 3(c), the pure $\mathrm{BiVO}_{4}$ crystal in the shape of decagon and polyhedron is monoclinic, which is consistent with the results of XRD. It can be observed that the pure $\mathrm{BiVO}_{4}$ particles own average size of 1-5 $\mu \mathrm{m}$, while due to the introduction of $\mathrm{GO} / \mathrm{g}-\mathrm{C}_{3} \mathrm{~N}_{4}$ in the system, $\mathrm{BiVO}_{4}$ crystals become more delicate and reduce to the size of 100 $500 \mathrm{~nm}$ (Fig. 3(d)), which may be affected by the chemical environment on the surface or edge of $\mathrm{GO} / \mathrm{g}-\mathrm{C}_{3} \mathrm{~N}_{4}$, such as hydroxyl and carbonyl that could easily limit the nucleation and growth process of the $\mathrm{BiVO}_{4}$ crystal. The layered structure of $\mathrm{GO} / \mathrm{g}-\mathrm{C}_{3} \mathrm{~N}_{4}$ may include stacking layers, which provides a site for the production and growth of $\mathrm{BiVO}_{4}$ particles, and are in accordance with the XRD results.
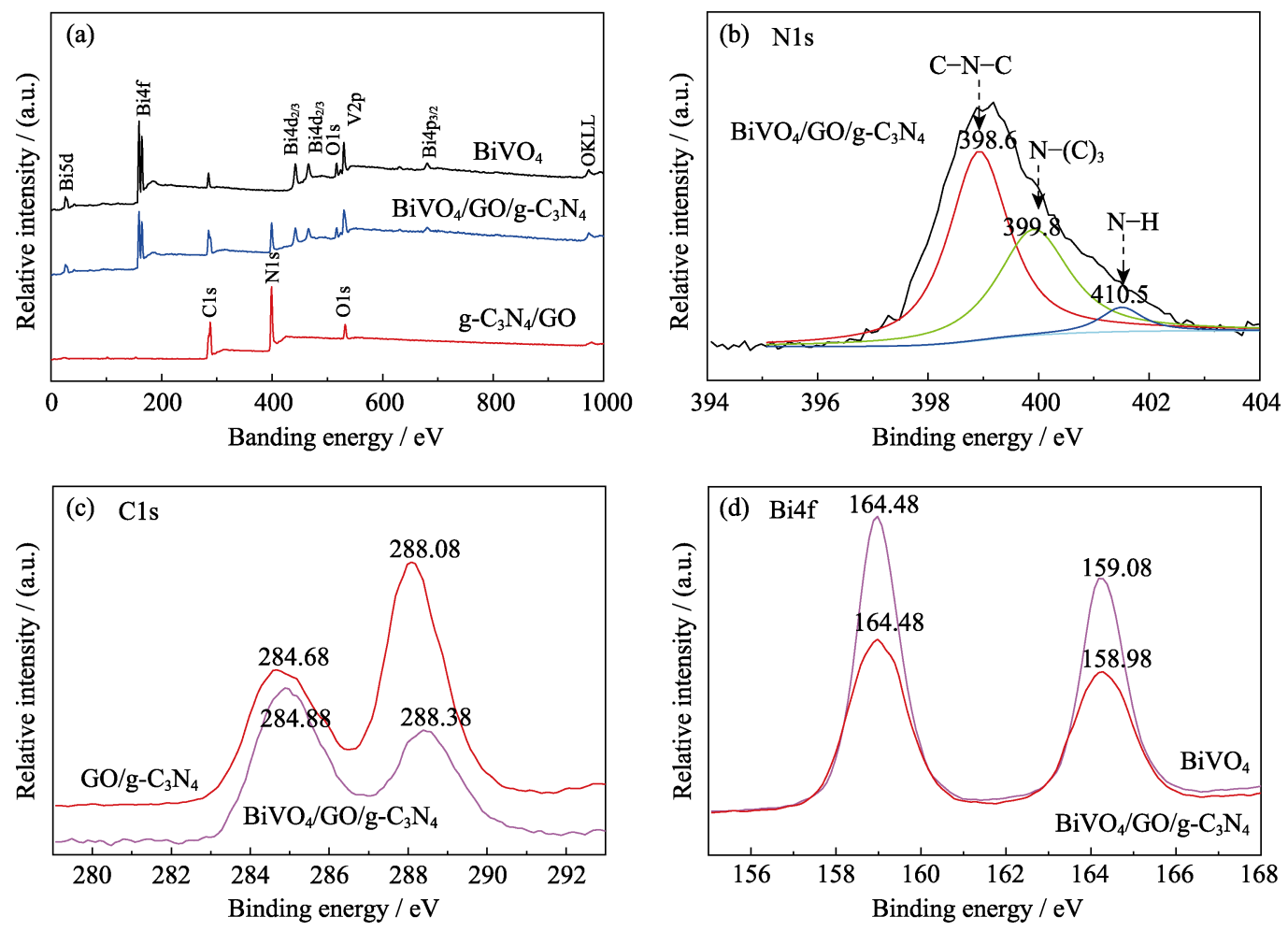

Fig. 2 XPS survey scans of $\mathrm{BiVO}_{4}, \mathrm{GO} / \mathrm{g}-\mathrm{C}_{3} \mathrm{~N}_{4}$ and $\mathrm{BiVO}_{4} / \mathrm{GO} / \mathrm{g}-\mathrm{C}_{3} \mathrm{~N}_{4}(\mathrm{a})$, and high-resolution spectra of N1s (b), C1s (c), Bils (d) in $\mathrm{BiVO}_{4}, \mathrm{GO} / \mathrm{g}-\mathrm{C}_{3} \mathrm{~N}_{4}$ and $\mathrm{BiVO}_{4} / \mathrm{GO} / \mathrm{g}-\mathrm{C}_{3} \mathrm{~N}_{4}$, respectively 

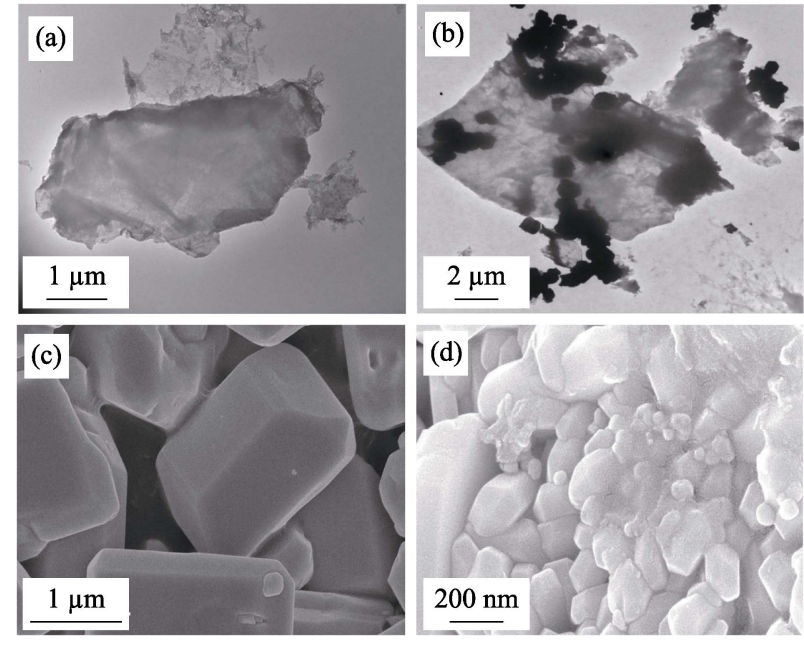

Fig. 3 TEM images of the as-prepared $\mathrm{GO} / \mathrm{g}-\mathrm{C}_{3} \mathrm{~N}_{4}$ (a) and $\mathrm{BiVO}_{4} / \mathrm{GO} / \mathrm{g}-\mathrm{C}_{3} \mathrm{~N}_{4}(\mathrm{~b})$, and SEM images of $\mathrm{BiVO}_{4}$ (c) and $\mathrm{BiVO}_{4} / \mathrm{GO} / \mathrm{g}-\mathrm{C}_{3} \mathrm{~N}_{4}(\mathrm{~d})$

The optical property of semiconductor photocatalysts plays a significant role in investigating the energy band structure for the photocatalytic activity. The UV-Vis diffuse reflectance spectra (DRS) of the obtained samples were revealed in Fig. 4(a). The absorption edge of the as-synthesized pure $\mathrm{g}-\mathrm{C}_{3} \mathrm{~N}_{4}$ is at about $556 \mathrm{~nm}$, while a broader absorption edge is at about $550 \mathrm{~nm}$, suggesting that $\mathrm{BiVO}_{4}$ can effectively utilize visible light for photocatalysis. The addition of $\mathrm{GO}$ to the $\mathrm{GO} / \mathrm{g}-\mathrm{C}_{3} \mathrm{~N}_{4}$ composite increases the background absorption of the sample, allowing the sample to more fully utilize visible-light as compared with pure $\mathrm{g}_{-} \mathrm{C}_{3} \mathrm{~N}_{4}$. Moreover, B2GC8 exhibits similar absorption characteristics to pure $\mathrm{BiVO}_{4}$, indicating that the binding of $\mathrm{GO} / \mathrm{g}-\mathrm{C}_{3} \mathrm{~N}_{4}$ only on the surface of $\mathrm{BiVO}_{4}$ did not change the original lattice structure, which is consistent with XRD and SEM results. The widest visible light absorption of the ternary $\mathrm{BiVO}_{4} / \mathrm{GO} /$ g- $\mathrm{C}_{3} \mathrm{~N}_{4}$ composites show that $\mathrm{BiVO}_{4}, \mathrm{~g}-\mathrm{C}_{3} \mathrm{~N}_{4}$ and GO generate effective synergy.

The band gaps were elevated by the following Eq. (2):

$$
\alpha h v=A\left(h v-E_{\mathrm{g}}\right)^{n / 2}
$$

Where $\alpha, h, v$, and $A$ are absorption coefficient, Planck constant, light frequency, and a constant, respectively. The $n$ value is determined by the type of optical transition of semiconductors ( $n=1$ for direct transition and $n=4$ for indirect transition). $\mathrm{BiVO}_{4}$ belongs to the direct transition semiconductors but $\mathrm{g}-\mathrm{C}_{3} \mathrm{~N}_{4}$ direct transition semiconductors. Through data processing and analysis, the $E_{\mathrm{g}}$ values of $\mathrm{BiVO}_{4}(2.43 \mathrm{eV})$ and $\mathrm{g}^{-} \mathrm{C}_{3} \mathrm{~N}_{4}(2.7 \mathrm{eV})$ can be obtained respectively (Fig. 4(b)).

\subsection{Photocatalytic activity analyses}

The visible light photocatalytic degradation spectra of the $\mathrm{RhB}$ with obtained photocatalysts is showed in Fig. 5(a). It is apparent that $\mathrm{g}_{-} \mathrm{C}_{3} \mathrm{~N}_{4}$ and $\mathrm{BiVO}_{4}$ exhibit
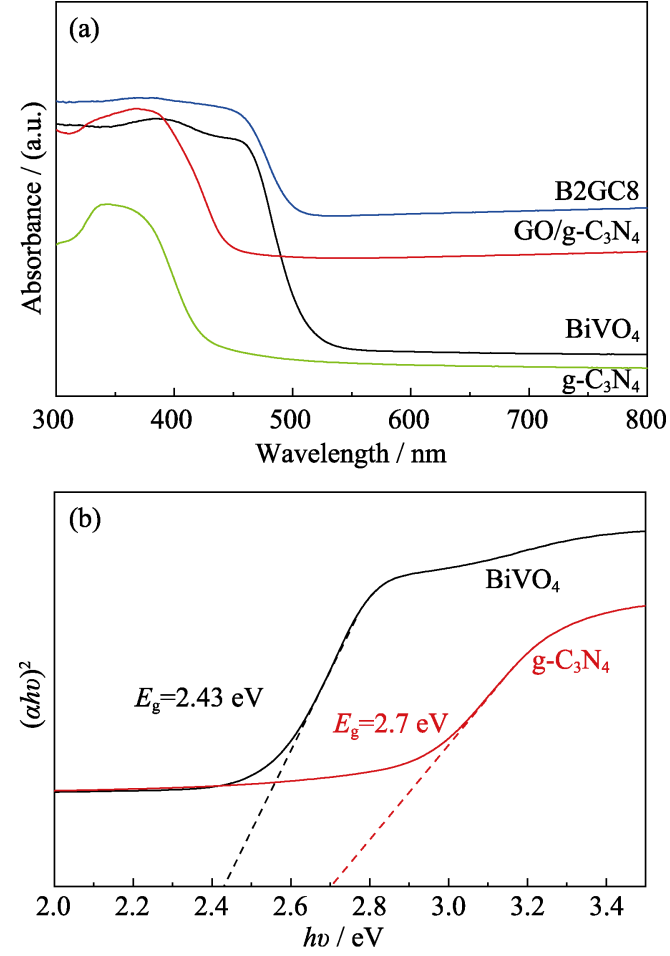

Fig. 4 UV-Vis adsorption spectra of prepared samples (a) and calculated band gap of $\mathrm{BiVO}_{4}$ and $g-\mathrm{C}_{3} \mathrm{~N}_{4}$ (b)

poor photocatalytic degradation of $\mathrm{RhB}$ solution activity under visible light owing to faster photogenerated electron/hole pair recombination and relatively narrow absorption of visible light regions, which is the same as the UV-Vis diffuse reflectance spectra.

Although $\mathrm{g}-\mathrm{C}_{3} \mathrm{~N}_{4}$ and $\mathrm{BiVO}_{4}$ respond to visible light, the effect is not significant, and the degradation efficiencies after irradiation for 120 min under visible light are $17 \%$ and $22 \%$. As contrasted with $\mathrm{g}-\mathrm{C}_{3} \mathrm{~N}_{4}$ and $\mathrm{BiVO}_{4}$, the photocatalytic degradation efficiency of $\mathrm{RhB}$ by $\mathrm{GO} / \mathrm{g}$ $\mathrm{C}_{3} \mathrm{~N}_{4}$ and $\mathrm{B} 2 \mathrm{GC} 8$ composites is significantly improved, reaching $51 \%$ and $85 \%$, respectively. The specific surface areas of $\mathrm{g}_{-} \mathrm{C}_{3} \mathrm{~N}_{4}, \mathrm{BiVO}_{4}, \mathrm{GO} / \mathrm{g}-\mathrm{C}_{3} \mathrm{~N}_{4}$ and B2CG8 are 7.6, $1.7,5.7,3.2 \mathrm{~m}^{2} \cdot \mathrm{g}^{-1}$, respectively. The calculated reaction rates per unit area were $0.197,1.17,0.68$, $3.29 \mathrm{mg} \cdot \mathrm{h}^{-1} \cdot \mathrm{m}^{-2}$, respectively. The degradation efficiency of the ternary $\mathrm{BiVO}_{4} / \mathrm{GO} / \mathrm{g}-\mathrm{C}_{3} \mathrm{~N}_{4}$ composite is higher than those of other catalysts, and the photoluminescence (PL) intensity of the ternary heterojunction was very low. The above results indicate that the $\mathrm{Z}$ scheme ternary photocatalyst has an effective redox capability and an excellent charge separation driving force to degrade RhB. The comparison results show that the Z-scheme ternary heterojunction has significant photocatalytic activity under visible light in terms of degradation of RhB.

Fig. 5(b) shows that the photocatalytic decomposition of $\mathrm{RhB}$ is supposed to follow a pseudo-first-order kinetics reaction, and the evaluating formula is expressed as Eq. (3): 

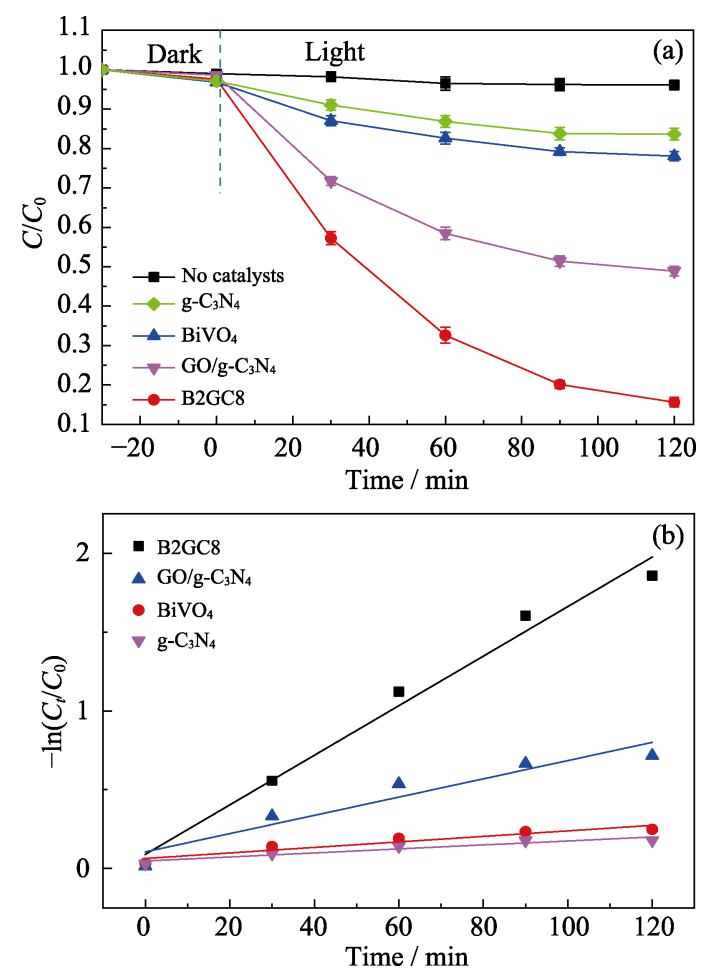

Fig. 5 Photocatalytic degradation of RhB (a) and dynamics of $\mathrm{RhB}$ photodegradation reaction $\left(\ln \left(C_{0} / C\right)\right.$ (b)

$$
\ln \left(C_{t} / C_{0}\right)=-k_{\text {app }} \times t
$$

Where $K_{\text {app }}$ is the apparent rate constant $\left(\mathrm{min}^{-1}\right), C_{0}$ and $C_{t}$ is the $\mathrm{RhB}$ concentration at reaction time 0 and $t$, respectively.

\subsection{Photoelectrochemical analyses}

In order to obtain more evidence that Z-scheme heterojunction promotes photocatalytic degradation of dyes, samples electrodes are recorded for several on-off cycles of irradiation. As can be seen from Fig. 6(a), the $I$ - $t$ curve of the synthetic sample was analyzed by a $30 \mathrm{~s}$ interval dark and visible light illumination cycle. When visible light is irradiated, the photocurrent value is gradually stabilized, and when the light is turned off, the photocurrent rapidly drops to zero, and this process can be cyclically reproduced. The performance indicates that the generated electrons move in the direction of the visible light, thereby generating a certain intensity of photocurrent. In the present case, the photocurrent diagram of
B2GC8 ternary heterojunction and $\mathrm{GO} / \mathrm{g}-\mathrm{C}_{3} \mathrm{~N}_{4}$ binary composites reveals an improved photocurrent response than that of the single $\mathrm{BiVO}_{4}$, which indicates excellent charge separation efficiency. This apparent enhancement of photocurrent also demonstrates that due to spatial isolation of photogenerated carriers at the interface between $\mathrm{BiVO}_{4}, \mathrm{GO}$ and $\mathrm{g}-\mathrm{C}_{3} \mathrm{~N}_{4}$, photogenerated electron-hole pairs achieves lower recombination and more efficient separation for the $\mathrm{GO} / \mathrm{g}-\mathrm{C}_{3} \mathrm{~N}_{4}$ composites. The reduced species in the electrolyte are trapped or captured the hole on the $\mathrm{BiVO}_{4}$ surface, while the electrons are effectively transported to $\mathrm{g}-\mathrm{C}_{3} \mathrm{~N}_{4}$ by $\mathrm{GO}$ sheets.

Photoluminescence (PL) analysis was carried out to reveal the intensity of the fluorescence emitted by the recombination of photogenerated electrons and the holes, thus inferring the process of migration, separation and recombination of photogenerated electrons and holes in catalyst. It is obvious that at an excitation wavelength of $315 \mathrm{~nm}, \mathrm{BiVO}_{4}$ is excited to a very strong steady-state fluorescence intensity, and the $\mathrm{GO} / \mathrm{g}-\mathrm{C}_{3} \mathrm{~N}_{4}$ composite is weaker than that of $\mathrm{BiVO}_{4}$, which is attributed to the fact that GO can act as an electronic repository to facilitate charge transfer and inhibit charge recombination in Fig. 6(b). The B2GC8 composite was excited to have the weakest fluorescence intensity, indicating that it has a lowest recombination rate of photogenerated carriers under visible-light irradiation. This can be mainly attributed to the transfer of electrons excited on $\mathrm{BiVO}_{4}$ to the valence band of $\mathrm{g}-\mathrm{C}_{3} \mathrm{~N}_{4}$ through $\mathrm{GO}$, while the holes on g- $\mathrm{C}_{3} \mathrm{~N}_{4}$ are transferred to the conduction band of $\mathrm{BiVO}_{4}$ through GO, thereby achieving spatial isolation of the two carriers. As a result to some extent, direct recombination of electrons and holes was prevented.

Electrochemical impedance (EIS) is an effective method for analyzing the improved charge separation efficiency, which is also conducted in Fig. 6(c). It depicted the magnitude of the impedance arc diameter under sample illumination, g- $\mathrm{C}_{3} \mathrm{~N}_{4}>\mathrm{BiVO}_{4}>\mathrm{GO} / \mathrm{g}-\mathrm{C}_{3} \mathrm{~N}_{4}>$ $\mathrm{B} 2 \mathrm{GC} 8$, indicating that the $\mathrm{B} 2 \mathrm{GC} 8$ ternary coupled photocatalyst has the ability to rapidly transfer and separate photogenerated carriers. This result is consistent with the effect of the RhB degradation experiment.
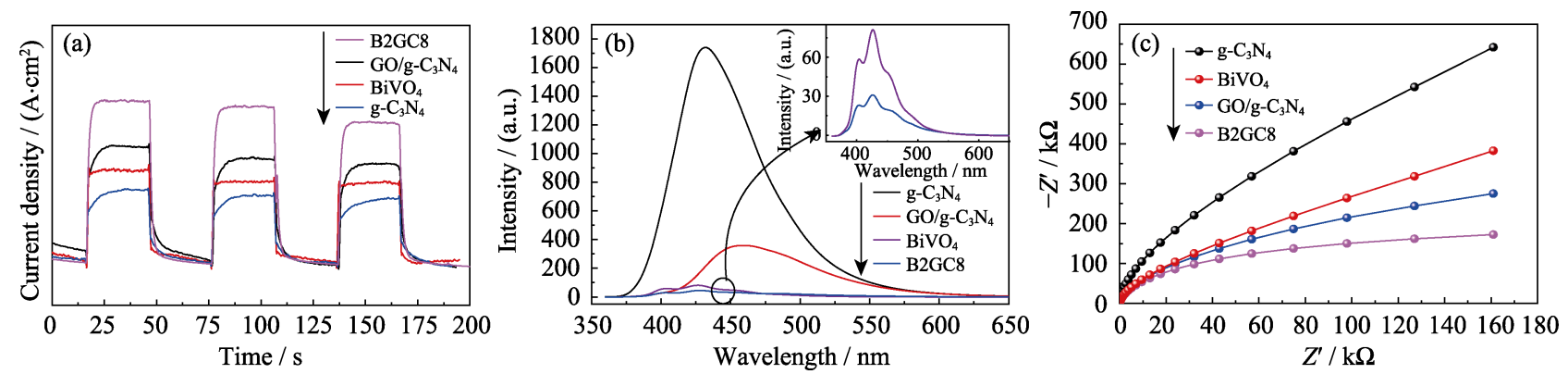

Fig. 6 Transient photocurrent responses (a), photoluminescence (PL) spectra (b), and EIS Nyquist plots (dot) (c) of g- $\mathrm{C}_{3} \mathrm{~N}_{4}, \mathrm{BiVO}_{4}, \mathrm{GO} / \mathrm{g}-\mathrm{C}_{3} \mathrm{~N}_{4}$ and $\mathrm{BiVO}_{4} / \mathrm{GO} / \mathrm{g}-\mathrm{C}_{3} \mathrm{~N}_{4}$ 


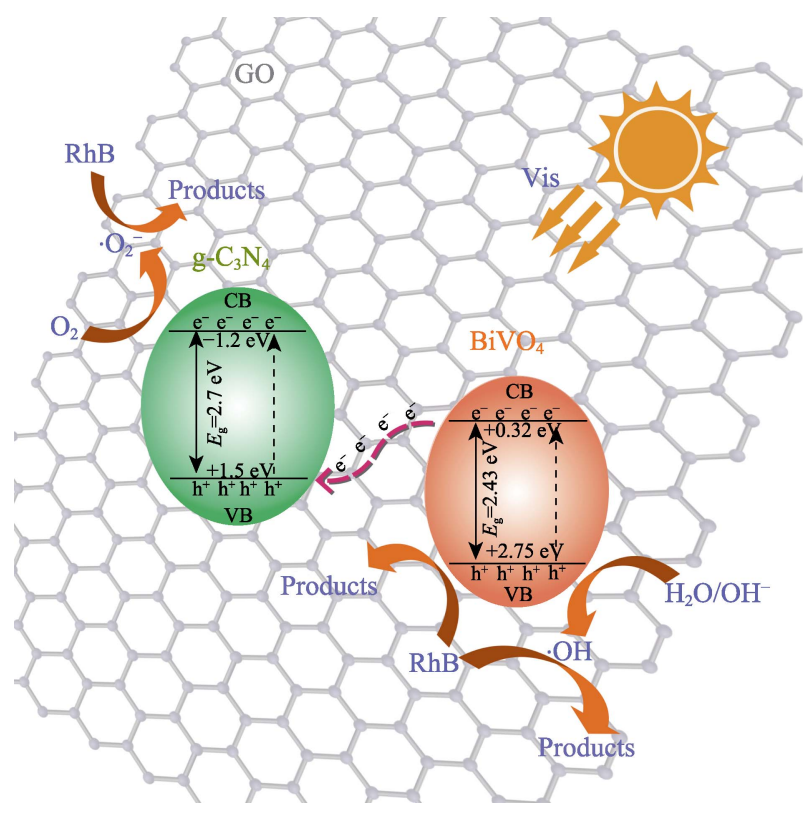

Fig. 7 Possible photocatalytic enhanced mechanism over $\mathrm{BiVO}_{4} / \mathrm{GO} / \mathrm{g}-\mathrm{C}_{3} \mathrm{~N}_{4} \mathrm{Z}$-scheme photocatalysts under visible light irradiation

\subsection{Photocatalytic mechanism analyses}

Through the above characterization results and analysis, the potential photocatalytic mechanism of the Z-scheme $\mathrm{BiVO}_{4} / \mathrm{GO} / \mathrm{g}-\mathrm{C}_{3} \mathrm{~N}_{4}$ ternary photocatalyst was tentatively proposed, and the reaction process was illustrated in Fig. 7. Due to the energy band gap of 2.43 and $2.7 \mathrm{eV}, \mathrm{BiVO}_{4}$ and $\mathrm{g}-\mathrm{C}_{3} \mathrm{~N}_{4}$ can be excited even under visible light irradiation, resulting in electron hole separation. According to the different conduction band and valence band position of the $\mathrm{BiVO}_{4}$ and $\mathrm{g}-\mathrm{C}_{3} \mathrm{~N}_{4}, \mathrm{~g}-\mathrm{C}_{3} \mathrm{~N}_{4}$ and $\mathrm{BiVO}_{4}$ anchored on $\mathrm{GO}$ by strong interfacial electrostatic interaction to form a Z-scheme heterojunction. Under the interface Z-scheme heterostructure, the photogenerated electrons in the $\mathrm{CB}$ of $\mathrm{BiVO}_{4}$ spontaneously move to the $\mathrm{VB}$ g- $\mathrm{C}_{3} \mathrm{~N}_{4}$ and $\mathrm{BiVO}_{4}$. The interface $\mathrm{Z}$-scheme heterostructure results in spatial segregation of photogenerated carriers and then accumulates electrons and holes. The electrons in the $\mathrm{CB}$ of $\mathrm{g}-\mathrm{C}_{3} \mathrm{~N}_{4}$ respectively generate $\cdot \mathrm{OH}$ radicals, and $\cdot \mathrm{O}^{2-}$ has strong oxidation, and then induce $\mathrm{RhB}$ degradation together with the holes. Therefore, the photocatalytic performance of the g- $\mathrm{C}_{3} \mathrm{~N}_{4} / \mathrm{GO} / \mathrm{BiVO}_{4}$ ternary heterostructure can be significantly enhanced.

\section{Conclusions}

A new Z-scheme photocatalyst of ternary $\mathrm{BiVO}_{4} / \mathrm{GO} / \mathrm{g}$ $\mathrm{C}_{3} \mathrm{~N}_{4}$ composites was successfully synthesized and employed for the photocatalytic degradation of RhB. In the photocatalytic process of $\mathrm{BiVO}_{4} / \mathrm{GO} / \mathrm{g}-\mathrm{C}_{3} \mathrm{~N}_{4}$, GO nanosheet act as fast transmission channels between $\mathrm{BiVO}_{4}$ and g- $\mathrm{C}_{3} \mathrm{~N}_{4}$ and can suppress electron-hole recombination, which significantly promotes the charge separation and improves the redox ability of the ternary heterojunction. As a result, about $85 \%$ of $\mathrm{RhB}$ dye was degraded by the ternary composites after $120 \mathrm{~min}$ visible light irradiation, superior to that of the single or binary system. In addition, the enhanced degradation efficiency could be ascribed to the active $\mathrm{h}^{+}$species in degradation progress in trapping experiment. Overall, the $\mathrm{Z}$-scheme $\mathrm{BiVO}_{4} / \mathrm{GO} / \mathrm{g}-\mathrm{C}_{3} \mathrm{~N}_{4}$ is an excellent photocatalyst with high-efficiency and has good potential for further application to organic-pollutants decomposition.

\section{References:}

[1] TEH C M, MOHAMED A R. Roles of titanium dioxide and iondoped titanium dioxide on photocatalytic degradation of organic pollutants (phenolic compounds and dyes) in aqueous solutions: a review. Journal of Alloys and Compound, 2011, 509(5): 1648-1660.

[2] RAMYA R, KRISHNAN P S, KRISHNAN M NEELAVENI, et al. Enhanced visible light activity of $\mathrm{Pr}-\mathrm{TiO}_{2}$ nanocatalyst in the degradation of dyes: effect of $\mathrm{Pr}$ doping and $\mathrm{TiO}_{2}$ morphology. $J$. Nanosci. Nanotechnol., 2019, 19(7): 3971-3981.

[3] RIAZ U, ASHRAF S M, KASHYAP J. Role of conducting polymers in enhancing $\mathrm{TiO}_{2}$-based photocatalytic dye degradation: a short review. Polymer-Plastics Technology and Engineering, 2015, 54(17): 1850-1870.

[4] HUNGE Y M, YADAV A A, MAHADIK M A, et al. Degradation of organic dyes using spray deposited nanocrystalline stratified $\mathrm{WO}_{3} / \mathrm{TiO}_{2}$ photoelectrodes under sunlight illumination. Optical Materials, 2018, 76: 260-270.

[5] PIRHASHEMI M, HABIBI-YANGJEH A, RAHIM POURAN S. Review on the criteria anticipated for the fabrication of highly efficient ZnO-based visible-light-driven photocatalysts. Journal of Industrial and Engineering Chemistry, 2018, 62: 1-25.

[6] MASSEY A T, GUSAIN R, KUMARI S, et al. Hierarchical microspheres of $\mathrm{MoS}_{2}$ nanosheets: efficient and regenerative adsorbent for removal of water-soluble dyes. Industrial \& Engineering Chemistry Research, 2016, 55(26): 7124-7131.

[7] $\mathrm{HE} \mathrm{H,} \mathrm{ZHOU} \mathrm{Y,} \mathrm{KE} \mathrm{G,} \mathrm{et} \mathrm{al.} \mathrm{Improved} \mathrm{surface} \mathrm{charge} \mathrm{transfer} \mathrm{in}$ $\mathrm{MoO}_{3} / \mathrm{BiVO}_{4}$ heterojunction film for photoelectrochemical water oxidation. Electrochimica Acta, 2017, 257: 181-191.

[8] ZHAO Z, ZHANG W, SHEN X, et al. Preparation of g- $\mathrm{C}_{3} \mathrm{~N}_{4} / \mathrm{TiO}_{2}$ / $\mathrm{BiVO}_{4}$ composite and its application in photocatalytic degradation of pollutant from TATB production under visible light irradiation. Journal of Photochemistry and Photobiology A: Chemistry, 2018 358: $246-255$.

[9] WANG K, ZHANG G, LI J, et al. 0D/2D Z-scheme heterojunctions of bismuth tantalate quantum dots/ultrathin $\mathrm{g}-\mathrm{C}_{3} \mathrm{~N}_{4}$ nanosheets for highly efficient visible light photocatalytic degradation of antibiotics. ACS Appl. Mater. Interfaces, 2017, 9(50): 43704-43715.

[10] FENG J, GAO M, ZHANG Z, et al. Comparing the photocatalytic properties of $\mathrm{g}-\mathrm{C}_{3} \mathrm{~N}_{4}$ treated by thermal decomposition, solvothermal and protonation. Results in Physics, 2018, 11: 331-334.

[11] YAN J, SONG Z, WANG X, et al. Enhanced photocatalytic activity of ternary $\mathrm{Ag}_{3} \mathrm{PO}_{4} / \mathrm{GO} / \mathrm{g}-\mathrm{C}_{3} \mathrm{~N}_{4}$ photocatalysts for Rhodamine B degradation under visible light radiation. Applied Surface Science, 2019, 466: 70-77.

[12] TAN Y, SHU Z, ZHOU J, et al. One-step synthesis of nanostructured $\mathrm{g}-\mathrm{C}_{3} \mathrm{~N}_{4} / \mathrm{TiO}_{2}$ composite for highly enhanced visible-light 
photocatalytic $\mathrm{H}_{2}$ evolution. Applied Catalysis B: Environmental, 2018, 230: 260-268.

[13] XIE Z, FENG Y, WANG F, et al. Construction of carbon dots modified $\mathrm{MoO}_{3} / \mathrm{g}-\mathrm{C}_{3} \mathrm{~N}_{4}$ Z-scheme photocatalyst with enhanced visible-light photocatalytic activity for the degradation of tetracycline. Applied Catalysis B: Environmental, 2018, 229: 96-104.

[14] NIE N, ZHANG L, FU J, et al. Self-assembled hierarchical direct $\mathrm{Z}$-scheme g- $\mathrm{C}_{3} \mathrm{~N}_{4} / \mathrm{ZnO}$ microspheres with enhanced photocatalytic $\mathrm{CO}_{2}$ reduction performance. Applied Surface Science, 2018, 441: $12-22$.

[15] LI Y, WU X, HO W, et al. Graphene-induced formation of visiblelight-responsive $\mathrm{SnO}_{2}-\mathrm{Zn}_{2} \mathrm{SnO}_{4} \mathrm{Z}$-scheme photocatalyst with surface vacancy for the enhanced photoreactivity towards $\mathrm{NO}$ and acetone oxidation. Chemical Engineering Journal, 2018, 336: 200-210.

[16] DENG Y C, TANG L, ZENG G M, et al. Facile fabrication of mediator-free Z-scheme photocatalyst of phosphorous-doped ultrathin graphitic carbon nitride nanosheets and bismuth vanadate composites with enhanced tetracycline degradation under visible light. Journal of Colloid and Interface Science, 2018, 509: 219-234

[17] WU Q, BAO S, TIAN B, et al. Double-diffusion-based synthesis of $\mathrm{BiVO}_{4}$ mesoporous single crystals with enhanced photocatalytic activity for oxygen evolution. Chem. Commun. (Camb), 2016, 52(47): 7478-7481.

[18] WU X, ZHAO J, WANG L, et al. Carbon dots as solid-state electron mediator for $\mathrm{BiVO}_{4} / \mathrm{CDs} / \mathrm{CdS} \mathrm{Z}$-scheme photocatalyst working under visible light. Applied Catalysis B: Environmental, 2017, 206: 501-509.
[19] LIU Q, GUO Y, CHEN Z, et al. Constructing a novel ternary $\mathrm{Fe}(\mathrm{III}) /$ graphene/g- $\mathrm{C}_{3} \mathrm{~N}_{4}$ composite photocatalyst with enhanced visible-light driven photocatalytic activity via interfacial charge transfer effect. Applied Catalysis B: Environmental, 2016, 183: 231-241.

[20] XIANG Q, YU J, JARONIEC M. Preparation and enhanced visible-light photocatalytic $\mathrm{H}_{2}$-production activity of graphene $/ \mathrm{C}_{3} \mathrm{~N}_{4}$ composites. The Journal of Physical Chemistry C, 2011, 115(15): 7355-7363.

[21] XUE B, JIANG H Y, SUN T, et al. ZnS@g- $\mathrm{C}_{3} \mathrm{~N}_{4}$ composite photocatalysts: in situ synthesis and enhanced visible-light photocatalytic activity. Catalysis Letters, 2016, 146(10): 2185-2192.

[22] HUANG Y, ZHANG X, ZHU G, et al. Synthesis of silver phosphate/sillenite bismuth ferrite/graphene oxide nanocomposite and its enhanced visible light photocatalytic mechanism. Separation and Purification Technology, 2019, 215: 490-499.

[23] ZHANG R, HUANG Z, LI C, et al. Monolithic g- $\mathrm{C}_{3} \mathrm{~N}_{4} /$ reduced graphene oxide aerogel with in situ embedding of Pd nanoparticles for hydrogenation of $\mathrm{CO}_{2}$ to $\mathrm{CH}_{4}$. Applied Surface Science, 2019, 475: 953-960.

[24] DOWLA B M R U, CHO J Y, JANG W K, et al. Synthesis of $\mathrm{BiVO}_{4}$-GO-PTFE nanocomposite photocatalysts for high efficient visible-light-induced photocatalytic performance for dyes. Journal of Materials Science: Materials in Electronics, 2017, 28(20): 15106-15117.

[25] LIN H, YE H, CHEN S, et al. One-pot hydrothermal synthesis of $\mathrm{BiPO}_{4} / \mathrm{BiVO}_{4}$ with enhanced visible-light photocatalytic activities for methylene blue degradation. RSC Advances, 2014, 4(21): 10968.

\title{
$\mathrm{Z}$ 型 $\mathrm{BiVO}_{4} / \mathrm{GO} / \mathrm{g}-\mathrm{C}_{3} \mathrm{~N}_{4}$ 复合材料的制备及其可见光下催化性能
}

\author{
许世超 $^{1}$, 朱天哲 ${ }^{1}$, 乔 阳 $^{2}$, 白学健 ${ }^{2}$, 唐 楠 ${ }^{1}$, 郑春明 ${ }^{2}$ \\ (天津工业大学 1. 环境科学与工程学院; 2. 化学化工学院, 天津 300389)
}

摘 要: Z-型光催化剂可以有效增强电荷分离, 从而改善光催化剂的活性。采用浸渍-煅烧和水热法两步制备 $\mathrm{Z}$ 型 $\mathrm{BiVO}_{4} / \mathrm{GO} / \mathrm{g}-\mathrm{C}_{3} \mathrm{~N}_{4}$ 光催化剂, 并用不同手段对其进行表征。在 $\mathrm{BiVO}_{4} / \mathrm{GO} / \mathrm{g}-\mathrm{C}_{3} \mathrm{~N}_{4}$ 的光催化过程中, $\mathrm{GO}$ 纳米片作为 $\mathrm{BiVO}_{4}$ 和 $\mathrm{g}-\mathrm{C}_{3} \mathrm{~N}_{4}$ 之间的快速传输通道, 可以抑制电子一空穴复合, 显著促进电荷分离, 提高三元异质结的氧化还原能力。 与单组分或二元复合物相比, 该催化剂具有良好的光降解罗丹明 $\mathrm{B}(\mathrm{RhB})$ 的能力。在可见光照射下, 它能够在 $120 \mathrm{~min}$ 内 降解 $85 \% \mathrm{RhB}$, 空穴 $\left(\mathrm{h}^{+}\right)$在反应中起主要作用。该工作为三元光催化剂体系提供了简单的制备方法, 其中 $\mathrm{g}-\mathrm{C}_{3} \mathrm{~N}_{4}$ 通过 $\mathrm{GO}$ 与 $\mathrm{BiVO}_{4}$ 偶联, 光催化活性显著提高。

关 键 词: $\mathrm{BiVO}_{4} ; \mathrm{g}-\mathrm{C}_{3} \mathrm{~N}_{4} ; \mathrm{GO}$; 三元催化剂; $\mathrm{Z}$ 型异质结

中图分类号: TB34 文献标识码: A 